\title{
Życiorys Batji Klig
}

\section{Wprowadzenie}

Poznałem panią Batję/Basię Klig (z męża Golan) około roku 2000, wkrótce po wydaniu Czarnych sezonów. Odwiedziła Polskę po raz pierwszy po tym, jak ją opuściła w roku 1946. Jeszcze w Izraelu jakimś cudem dowiedziała się, że w Polsce ukazała się książka, w której wspomina się jej matkę; rzeczywiście o pani Kligowej pojawia się wzmianka w tym opowiadaniu, w którym piszę o nielicznych uratowanych pruszkowskich Żydach, powracających do miasteczka tuż po zakończeniu wojny. Postanowiła do mnie dotrzeć. I dotarła. Za pierwszym razem odwiedziła mnie na Służewie nad Dolinką, następnym razem spotkaliśmy się w Komorowie u jej przyjaciół, u których się zatrzymała. Rozmowy dotyczyły między innymi pruszkowskich dziejów jej rodziny, chciała poznać miejsca, w których ona żyła; znała losy rodziców, pragnęła dowiedzieć się czegoś o dalszych krewnych. Niestety, to się nie powiodło, nie pozostały żadne ślady, a z ludzi, którzy mogli coś wiedzieć i powiedzieć, nie ma już nikogo wśród żywych.

Nie wiedziałem wówczas, że pani Basia w roku 1946 zrelacjonowała swoje przeżycia z czasów Zagłady. Przed rokiem do mnie zadzwoniła i zapytała, czy mnie interesuje jej tekst, napisany tuż po zakończeniu wojny, opowiadający o tym, czego doświadczyła w latach Zagłady, jeśli tak, to mi go przyśle. Wkrótce nadeszła kserokopia. Jest to tekst niezwykły. Pisany przez jedenastoletnią dziewczynkę, zdumiewa nie tylko swym autentyzmem i konkretnością, zdumiewa także wręcz niebywałą dojrzałością. To dziecko wie, o czym ma pisać, trzyma się tematu, nie zapuszcza $\mathrm{w}$ dygresje, nie pozwala sobie na żadne emocjonalne komentarze. Jest rzeczowe aż do bólu. Pani Basia jest ode mnie nieznacznie młodsza (o dwa miesiące); kiedy czytałem jej opowieść po raz pierwszy, zastanawiałem się nad tym, czy w roku 1946 byłbym w stanie napisać relację o moich doświadczeniach z czasu Zagłady. Doszedłem do przekonania, że nie było we mnie tej dojrzałości, która by mi na sporządzenie takiego tekstu pozwoliła.

Dokumentarne opowieści Dzieci Holokaustu (by się posłużyć nazwą działającego w Polsce stowarzyszenia) budzą duże zainteresowanie historyków, badaczy literatury, psychologów, są to bowiem przekazy jedyne w swoim rodzaju, niezwykłe. Stanowią świadectwo pierwszej wagi, mówią o strasznych czasach na swój sposób, inaczej, a w pewnych przypadkach - paradoksalnie - więcej niż relacje osób dorosłych. Teraz do tej ważnej serii dołącza tekst, który pani Basia wyciągnęła na światło dzienne z czeluści szuflady. Jeśli o Zagładę chodzi, każdy dokument biograficzny jest ważny, każdy życiorys osoby, której udało się przeżyć, jest jedyny w swoim ro- 
dzaju, niepowtarzalny, taki, jakiego nie wymyśliłby nawet utalentowany beletrysta, nienapotykający trudności w budowaniu fabuł.

Chana Kligowa wysłała swą nieletnią córkę do Palestyny w roku 1946, bała się o jej przyszłość w Polsce (był to rok pogromu w Kielcach), sama wyjechała do Izraela kilka lat później. Pani Basia/Batja Golan-Klig do dzisiaj mieszka w kibucu Gan-Shmuel, przed przejściem na emeryturę pracowała w nim jako bibliotekarka, ma pięcioro dzieci (obecnie już dorosłych) i sporą gromadkę wnuków. Zachowała sentyment do kraju swojego dzieciństwa, zwłaszcza zaś do Pruszkowa, w którym przyszła na świat.

Michał Gtowiński 


\section{Basia (Batja) Klig}

\section{$\dot{Z}_{\text {yciorys }}{ }^{1}$}

Batja Klig rok 1935 dnia 20 stycznia w Pruszkowie, tatuś nazywał się Leon Klig, matka nazywała się Chana Wilner.

Rodzice moi mieli przed wojną sklep galanteryjno-blacharski. Ojciec mój zajmował się blacharstwem, a matka pomagała mu w sklepie i zajmowała się mną. Kiedy miałam trzy lata, zaczęłam chodzić do freblówki żydowskiej, ale gdy wojna się rozpoczęła, przestałam chodzić. Kiedy wkroczyli Niemcy do Polski, zaczęli prześladować żydowskich mężczyzn i znęcać się nad nimi. W naszym miasteczku chodzili po ulicach antysemici polscy i zaczęli buntować Polaków, żeby nie mieli żadnych styczności z Żydami. Po tym wszystkim chcieli nas wszystkich Żydów wypędzić z mojego miasteczka. Judenrad oznajmił, że który mężczyzna pójdzie ochotniczo pracować do warsztatów kolejowych, które się w naszym miasteczku mieściły, to cała rodzina jego pozostanie na miejscu. Ojciec mój zgłosił się pracować, aby tylko jego rodzinę nie wysiedlili. Jeszcze [wielu] Żydów zgłosiło się do pracy, ale okazało się, że to tylko był podstęp. Po 2 dniach w 194022 stycznia wysiedlili nas wszystkich do getta w naszym miasteczku, a potem $z$ tamtąd do getta Warszawskiego już bez mężczyzn. Po drodze nam wszystkie rzeczy najlepsze zabrali i zaprowadzili nas do jednego domu, w którym nas rewidowali i ścinali włosy.

Po tej rewizji przekupiliśmy wartę i weszliśmy do getta na Niską Nr 33 do wujka. Wujek ten miał 7 dzieci i żonę i był biedny. Po krótkim pobycie u wujka wyprowadziliśmy się z całą rodziną na ulicę Ogrodową 24 . Z początku żyliśmy dobrze, ale później nie mieliśmy już nic co do sprzedania, wszystko się wyczerpało. W dodatku tatuś mój był w obozie i matka go musiała wykupić, ażeby jej pomógł utrzymać mnie i całą rodzinę. Matka moja umówiła się z Ojcem pewnego dnia, żeby uciekł z obozu, gdyż tam było niebezpiecznie i bili ich i katowali na każdym miejscu. Umówili się o godz. 2, żeby tatuś był u jednego polaka, który się nazywał Karol Polakiewicz. Mamusia zamiast pójść do tego polaka, poszła do obozu. Gdy się zbliżyła do bramy, ujrzał ją jeden żyd naczelnik, który się nazywał Śliwkiewicz. On natomiast zawołał Niemców i powiedział im, że teraz przyszła p. Klig, której mąż dzisiaj uciekł. Złapali Niemcy moją mamusię i wsadzili ją do więzienia i oznajmili, że dopóki tatuś się nie zgłosi, mamusia będzie siedzieć w więzieniu. Tatuś, gdy się dowiedział, że mamusia siedzi w więzieniu, postanowił wrócić spowrotem, nie zważając na nic. Mamusia jeszcze siedziała w więzieniu i Niemcy nie dawali jej jeść. Jeden żyd znajomy podawał mamusi jeść, żeby Niemcy nie widzieli, i mamusia nie głodowała.

${ }^{1}$ Życiorys Basi (Batji) Klig, jak wynika z dokumentu, pisany był przed wyjazdem z Polski w 1946 r. Nie był nigdzie wcześniej publikowany. Zachowano pisownię oryginału, uwspółcześniono jedynie interpunkcję. 
Po 8-miu dniach trzymania mamusi w więzieniu Niemcy mieli ją wypuścić. W tym samym dniu tatuś wrócił, aby mamusię wypuścić. Wówczas Niemcy wypuścili mamusię i wzięli tatusia, aby się znęcać nad nim. Niemcy wzięli tatusia, położyli go na dwóch stołkach i kazali mu się rozebrać. Potem przyszło dwóch małych Volksdeutszów z naganami w rękach i zaczęli go bić. Pierwsze uderzenie bolało, jakby mucha ukąsiła, a później wogóle nie czuł. Tak go bili 15 minut, potem go wrzucili do (piwnicy) trupiarni, tam tatuś leżał 56 godz. I nic mu nie dali jeść i lali na niego wodę i popiół. Po 56 godzinach kazali tatusiowi zdjać koszulę i umyć podłogę. Po tych wszystkich katorgach złamali tatusiowi rękę. Mamusia powróciła do getta i opowiedziała nam o tym wszystkim. Głód wtedy panował, po ulicach chodzili biedni i zbierali okruchy po[d] kramami. Gdy zobaczyli wystawę, na której był chleb i masło, i inne rzeczy, wtedy wybijali wystawę i mówili „Dyj un [in?] myjer cy jach cu dijer”2. Policjanci żydowscy, gdy to widzieli, złapali takiego człowieka i dotąd go kopali i bili, aż go nie zabili. Ciocia moja przez cały czas nie obecności mamusi chodziła ze mną po ulicach i kupowała mi dużo cukierków i tym żywiliśmy się. Bo cukierki były najtańsze.

Potem mamusia wróciła do Pruszkowa do obozu, wykupiła tatusia i wróciła wraz z tatusiem do Warszawy do Getta. Gdy tatuś wrócił, było nam już lżej żyć. Wynajęliśmy sobie drugie mieszkanie na samym poddaszu. Tatuś chodził do znajomego blacharza i tam pracował, aby nas wyżywić i za mieszkanie zapłacić. Gdy razu pewnego mamusia upiekła czulent i niosła go od piekarza, podbiegł jeden chłopiec i dwoma pięściami uderzył w garnek i uciekł. Podeszła do mojej mamusi jedna żydówka i powiedziała: nie wie p[ani,] czego on tak uderzył w ten garnek pięściami, on chciał, żeby czulent się wysypał na ziemię i on pozbiera i zje. Potem w ten sam dzień ja, idąc z mamusią ulicą, widziałam prawie że ten sam obraz. Idzie jedna p[ani] umalowana, niesie biały chleb po[d] ręką, podchodzi biedny człowiek spuchnięty i wynędzniały, wyrywa jej ten chleb i ucieka. Dogania go żydowski policjant, wyrywa mu ten chleb i zaczął go kopać, krew się broczyć zaczęła i on padł, i skonał. Idziemy dalej, widzimy na ulicy Leszno pełno trupów zakrytych papierami i popuchniętych z głodu. Po tym wszystkim wróciłyśmy do domu, zmrok już zapadał. Patrolki Niemieckie jechali i wszędzie były wachy obstawione Niemcami, policjantami żydowskimi. Po powrocie do domu położyłyśmy się spać. Pluskwy (pchły) były straszne w tym mieszkaniu, tak że wynieśliśmy się spać do korytarza. Po tym wszystkim pobyliśmy parę dni w gecie i postanowiliśmy uciec z Warszawy.

Na następny dzień pożegnaliśmy się z całą rodziną, która mieszkała także w gecie na ulicy Elektoralnej i na Ogrodowej 24. Wieczorem chcieliśmy się przekraść na aryjską stronę. Doszliśmy do jednej dziury, lecz tam byli Niemcy i [nie] można było się przedostać przez mur. Zawróciliśmy spowrotem i zaczekaliśmy godzinę,

${ }^{2}$ Dyj un [in?] myjer cy jach cu dijer (jidysz) - można to zdanie tłumaczyć jako „ty do mojego czy ja do twojego”, co można by interpretować: „twoje jedzenie przyjdzie do mnie/ mojego żołądka, albo ja pojdę do ciebie/po twoje [jedzenie]”. 
aż Niemcy odejdą, po godzinie przeczołgaliśmy się przez ten mały otwór na polską dzielnicę. Szliśmy z 5 godzin, nim doszliśmy do dworca Wschodniego. Patrzymy, a tu pełno Niemców, zasiedli do wagonów i zajęli wszystkie miejsca. My chcemy wejść do wagonu, jest okropne przepełnienie, tatuś miał ze sobą skrzynkę nie dużą, w której była kolba do lutowania, kawałek cyny i jeszcze inne przyrzondy. Tatuś, gdy się chciał wepchnąć do wagonu, ukuł przez nie ostrożność jedną polkę. Ona natomiast zaczęła się kłócić, w tym momęcie nadbiegł (policjant) konduktor z latarką i poznał tatusia, że jest żyd. Mamusia już była w wagonie. Przed ucieknięciem z getta mówiła mi mamusia, że jak poznają tatusia, żebym ja poszła z tatusiem, to go nie będą tak bić. Ja, nie namyślając się dużo, podeszłam do tatusia. Kolejarz odrazu zawołał gestapo, które nas zaprowadziło na 7-dme piętro na badanie. Najpierw zaczęli tatusia badać, a ja przez ten czas siedziałam i płakałam. Zaczęli tatusiowi zadawać różne pytania, dlaczego uciekł z getta? Do kogo teraz chciał jechać itd. Mnie te same pytania pytali się Niemcy, na co ja tak samo odpowiadałam. Po tym badaniu zaprowadzili nas na drugą stronę ulicy do więzienia. Było tam 15 osób, pomiędzy nimi były kobiety, mężczyżni, dwoje małych dzieci. Była to mała wąska sionka, która była przegrodzona na pół, w jednej połowie my byliśmy i 15 żydów, a w drugiej połowie były kraty i siedziało dwóch więźniów na pryczach drewnianych. Przez noc wszył mi tatuś parę złotych, żeby mu nie zabrali. Kilka razy w nocy przychodzili Niemcy i brali nas na badanie. Kiedy była już godzina 10 rano, zachciało nam się jeść. Jeden polak rzucił nam przez okno kromkę chleba, która wpadła na pryczę jednego więźnia z za kraty. Więzień ten oddał mi ten kawalek chleba. Tatuś nie chciał wziąść kawałek chleba, tylko kazał zjeść mi samej. Po tym posileniu nabrałam więcej siły. Potem zawołali nas Niemcy na jeszcze jedno badanie i kazali Polskiej policji zaprowadzić tatusia do więzienia do getta, a mnie puścić do getta. Uszliśmy kawałek aż do wachy i tam zabrali tatusia i mnie puścili. Teraz już zostałam bez ojca i bez matki, a miałam wtedy 6 lat. Ludzie mnie obstapili i zaczęli mnie się wypytywać różne pytania. Ja nie zważałam na nic, tylko szłam. Przypomniało mi się, że na 1 ulicy Grzybowskiej jest gmina żydowska, ja tam poszłam i opowiedziałam im o wszystkim, co się zdarzyło. Znałam wtedy adres mojej babci i cioci. Natychmiast zatelefonowali i przyszła po mnie najmłodsza cio[cia i] zabrała mnie do domu.

Odtąd byłam razem z nią i babcią i jeszcze dwoma ciociami. Od czasu do czasu otrzymywałam listy od mamusi z Lublina. Co dzień chodziłam z ciocią albo z babcią do tatusia do więzienia, ale go tylko jeden raz widziałam, jak niósł kocioł zupy z jeszcze jednym pod obserwacją policji żydowskiej. Tak byłam dwa tygodnie bez tatusia. Aż pewnego rana ktoś puka do drzwi, babcia wstała i otworzyła mu, patrzę i oczom nie wierzę, przede mną stanął tatuś. Od tego czasu było lżej żyć, tatuś starał się i pracował, jak tylko mógł. Pewnego dnia dostałam telegram od mamusi, żeby do niej przyjechać. Na drugi dzień przyjechał do nas jeden polski kolejarz i wyjechaliśmy z ciocią ja i kolejarz do mamusi.

W Warszawie przedostaliśmy się znów przez dziurę, ale już inną. Po drodze do pociągu spotkali nas polacy i chcieli, żebyśmy im dali łapówkę, bo inaczej to nas 
odprowadzą do Niemców. Po długich i ciężkich zatargach odczepiliśmy się od nich. Kolejarz nas wsadził do pociągu i pojechaliśmy do Lublina. Z Lublina poszliśmy piechotą $18 \mathrm{~km}$. W lesie kolejarz nam zginął, gdyż myśmy nie miały siły i nie mogłyśmy za nim nadążyć. Gdy się las skończył, zobaczyłam kilku chłopaków, których się pytałam, czy widzieli wysokiego kolejarza z walizką w ręku. Oni odpowiedzieli mi, że widzieli, ale już dawno poszedł. Ja zaczęłam biegać, aby go dogonić, lecz po godzinie dogoniłam go w jednej wsi. On mnie zaprowadził do jednego mieszkania, a sam poszedł poszukać mamusi. Ludzie ci mnie przyjęli i pytali mi się wiele pytań, na które im odpowiedziałam. Potem kazali mi się położyć na łóżko. Gdy się położyłam na łóżko i zasnęłam, mamusia przyszła, pocałowała mnie i się obudziłam. Gdy się obudziłam, zobaczyłam mamusię, która mi dała szklankę mleka. Potem poszłyśmy razem z mamusią do wujka i tam byłyśmy kilka tygodni, dopóki [nie] przyjechał wujek i tatuś. Tatuś zaczął tam pracować, wynajęliśmy sobie mieszkanie i mieszkaliśmy wszyscy razem ze dwa lata.

Później zachorowaliśmy wszyscy na tyfus, tylko tatuś co nie chorował. Po kilku tygodniach wszyscy byli już zdrowi i otrzymaliśmy wiadomość, żeby o 10 godzinie na drugi dzień stawić się do Bełżyc, tatuś nie chciał iść, ale ciocia powiedziała, może tam nam dadzą mieszkanie i będzie można tam żyć. Tatuś nie poszedł, tylko ja mamusia i ciocia. Przychodzimy tam, widzimy pełno żydów na ulicach, płaczą, krzyczą, nie mają gdzie się podziać. Ja powiedziałam do mamusi, mamusiu uciekajmy stąd, bo tu będzie źle. Mamusia mi odpowiedziała, że jutro powrócimy, bo dzisiaj jest już późno. Poszłyśmy do bóżnicy i przenocowałyśmy się. Rano budzimy się, już jest pełno Niemców, już okrążyli nas naokoło ${ }^{3}$. Mamusia ubrała chustkę, wzięła mnie pod rękę i ciocię za rękę. Na ulicach płacz, krzy[k] dzieci, rozłańczają młodych osobno, starych osobno. Chcemy się przedostać na drugą stronę, ale stoi warta i nas nie puszcza. Ukrainiec chce nam zabrać pieniądze, a jak mu nie damy, to nas zabije. Ciocia wyjęła pieniądze i mu oddała. Ciocia miała walizkę, którą nie chciała porzucić. Doszłyśmy do drugiego miejsca, na którym też była warta. Ciocię zaczepili i chcieli jej odebrać pakunek. My w minucie skręciłyśmy w boczną ulicę i schowałyśmy się do ustępu, który był tuż przy szkole. Huki i strzały nie ustawały, ziemia się trzęsła od wystrzałów. Tam przebyłyśmy ze dwie godziny, a później wypełzłyśmy stamtąd. Ciocia się została i nie wiedziałyśmy, co się z nią stało. My szłyśmy ze trzy kilometry, a później poprosiłyśmy jednego chłopa, który jechał do Prawiednik ${ }^{4}$, żeby nas zawiózł do Prawiednik. Chłop ten się zgodził i nas zawiózł. Kiedy przyjechałyśmy do Prawiednik, dowiedziałyśmy się, że tatuś jest na tej wsi. Tatuś przyszedł do nas i zapoznałyśmy jedną polkę, która się nazywa Stanisława

${ }^{3}$ Akcja wysiedleńcza w Bełżycach rozpoczęła się we wrześniu 1942 r., Żydów wywieziono na Majdanek. W dniach 9-12 października kazano Żydom z pobliskich gmin zgromadzić się w mieście. Prawdopodobnie wówczas autorka wspomnienia znalazła się w Bełżycach. 13 X 1942 r. ponad 7000 Żydów wywieziono z Bełżyc do obozu zagłady w Sobiborze.

${ }^{4}$ Prawiedniki - wieś w powiecie lubelskim, w gminie Głusk. 
Pacek $^{5}$. Ona miała dwóch synów, którzy się nazywali Jerzyk i Leszek. Jerzyk ma 27 lat, Leszek 21. Ona nas trzymała na strychu parę dni, ale później bała się nas trzymać. Mamusia i tatuś odeszli i zostawili mnie samą u niej. Mamusia i tatuś byli u jednego chłopa, który się nazywał Żak. Ona wzięła mnie i zaprowadziła do rodziców. Tatuś się okropnie zmartwił i zaczął ją prosić, żeby mnie nadal trzymała. Ona jednak bała się dłużej mnie trzymać i powiedziała, że nie może. Tatuś kazał mi iść na wieś i prosić kogoś, żeby trzymali, bo bał się że lada dzień chłop go wyrzuci na bruk i bał się, żeby nie oskarżyli go i ja mogę przy rodzicach zginąć, a tak to może prędzej przeżyję. Ja jednak nie odchodziłam od rodziców, tylko byłam razem.

Później poniewieraliśmy się troje razem. Razu pewnego spotkaliśmy się z wujkiem kilka razy i on nie miał gdzie przebywać, tułał się, każdy go wyganiał, bo bał się trzymać żyda bez żadnej legitymacji. Dużo było faktów, że chłopi oskarżali żydów, a jak Niemcy się dowiedzieli, to żyda zabili i polaka, który go przetrzymywał, również. Do nauczycielki Pacek przybywaliśmy bardzo często. Wszędzie ukrywaliśmy się w lasach, stodołach. Tatuś znał jednego chłopa, który się nazywał Orzep. Tam też przebywaliśmy, ale on też się bał. Razu jednego, było to w zimie, tatuś kazał mi odejść, bo przy nim to zginę, a mamusia żeby się została z tatusiem. Ja zaczęłam płakać strasznie. Mamusi się zrobiło żal puścić mnie samą, to postanowiła iść ze mną, a tatusia zostawić. Przed odejściem pożegnałyśmy się z tatusiem. Na pożegnanie powiedział nam tatuś ostatnie słowa do mamusi: „odchodzisz z dzieckiem, ale mnie już więcej nie zobaczysz”. Myśmy z mamusią odeszły, po drodze wstapiłyśmy do jednej znajomej, która nam dała ukłony od wujka, że go Niemcy złapali i siedzi w Piotrowicach w więzieniu i kazał jej nas pozdrowić. Potem poszłyśmy na wieś do jednej polki, która się nazywała Boczkowa, u niej siedziałyśmy na górce kilka miesięcy, ona nam przynosiła kilka razy dziennie jedzenie.

Po miesiącu czasu otrzymałyśmy wiadomość, że tatuś nie żyje. Mamusia poszła ze mną do Orzepa i dowiedzieliśmy się, że tatuś zachorował i nikt mu nie dawał jedzenie i on umarł. Więcej nam nie mówił i odeszłyśmy. Poszłyśmy do jego kuzyna, który nam powiedział, że jeszcze przyszedł do niego i powiedział: „tylko mi szkoda tego dziecka”. Po tym poszłyśmy do Pacek i ona nas trzymała, wynosiła nam co dzień jedzenie. Przy samym końcu już nie mogła nas trzymać. Pojechałyśmy z mamusią do Sobieszczan ${ }^{6}$ i tam zameldowałyśmy się jako polki. Ona nas trzymała trzy miesiące. Mamusia pracowała w domu i przy gospodarstwie. Ja pasłam siedem krów i zajmowałam się małym dzieckiem, które miało 8 miesięcy. Kiedy Niemcy już uciekli przyszli Rosjanie. Dwa tygodnie po nastaniu Rosjanów wróciłyśmy do Pacek, która nas prawie całą wojnę przetrzymała. Rok byłam u niej razem z mamusią. (I odwdzięczałyśmy się za) Po roku czasu powróciłyśmy z mamusią do Pruszkowa, do rodzinnego miasta. Tam chodziłam do szkoły powszechnej, do czwartej klasy.

${ }^{5}$ Stanisława Pacek wraz z synami Jerzym i Leszkiem została odznaczona medalem Sprawiedliwej wśród Narodów Świata 7 XII 1995 r. Oprócz Basi Klig i jej matki pomagała ona także innej żydowskiej uciekinierce z warszawskeigo getta - 12-letniej Sarze Kraus.

${ }^{6}$ Sobieszczany - wieś w powiecie lubelskim, w gminie Niedrzwica Duża. 
Było mi bardzo dobrze, ale pomimo wszystko przezywali mnie, że jestem żydówką. Mamusia oddała mnie do kibucu, w którym mi jest bardzo dobrze. Teraz już jestem pięć miesięcy w kibucu i w kibucu dowiedziałam się wiele rzeczy, o których nie wiedziałam. Jestem już w drodze do mojej Ojczyzny Erec Israel, do której tak pragnę przyjechać.

Batja Klig

\title{
Słowa kluczowe
}

Batja (Basia) Klig, Holocaust, getto warszawskie, Bełżyce, Sobieszczany, ukrywanie się na prowincji

\begin{abstract}
Memoir written in 1946 by the-then 11 year old Batja (Basia) Klig, who was in the Warsaw ghetto during the war, and then was kept in hiding in the provinces near Lublin.
\end{abstract}

\section{Key words}

Batja (Basia) Klig, Holocaust, Warsaw ghetto, Bełżyce, Sobieszczany, hiding in the provinces 